た. 2D PACE法のパラメータは, Scout TR150ms, Accept window $\pm 2.0 \mathrm{~mm}$, Position accept window Automaticとし, 撮像時間と 胸管の描出について検討を行った。

【結果】撮像時間は，3 分53秒から13分39秒まで大きく差がみられ た。胸管の描出は，上部，中部，下部の 3 等分とすると上部，中 部，下部すべて良好に描出される場合，上部と中部のみが良好な場 合や下部のみが描出されるなど描出能にばらつきがあった。

【考察】撮像時間は，Accept window内に横隔膜の位置がきた時に本久 キャンがスタートするので呼吸のパターン，速さやばらつきに影響 されたと考えられる，胸管の描出については，個々の生理的状態に よる影響や撮像パラメー夕によるものなどが考えられ，撮像時間短 縮を含めたさらなる最適化が必要と考えられる。

\section{2 磁場強度の違いがSPIO造影剤の造影能に及ぼす影響} 熊本大学・医学部保健学科 肥合康弘

熊本大学医学部附属病院·中央放射線部 小味昌憲, 橋田昌弘 中村 貴, 松岡史織, 清水紀恵, 斎藤英樹

【はじめに】当院では，1.5T超伝導MRI装置 2 台と0.4Tオープンタイ プMRI装置 1 台が稼動している。通常，磁場強度が低いとSNRの劣 化などのため病巣(腫崵など)の検出能は低下するといわれている。

しかし, SPIO系の造影剤を用いた検査で, 低磁場装置が高磁場装置 に比べて腫瘍のコントラストが高いと考えられる症例を多く経験し た。 そこで，低磁場装置の腫瘍検出能が向上したかを定量的に測定 し，その原因を検討した。

【方法】臨床例の検討として，1.5T装置と0.4T装置でリゾビスト静注 後撮像したT2*強調画像の腫瘍部と正常肝のCNRを測定し，また， 医師による視覚評価も行った。基礎的検討として, SPIO造影剂を $1.6 \mathrm{mmol} / /$ から $0.5 \mathrm{mmol} / /$ まで 5 段階に希釈した溶液と $2 \%$ のアガロー スでファントムを作成し, 磁場強度の異なる装置でのT1, T2, T2* 值拉よび，信号強度変化を測定した。

【結果と考察】1.5T装置と0.4T装置で撮像した10例のHCC患者におい て, T2*強調画像での腫瘍部と正常肝のCNRの平均值は, $0.4 \mathrm{~T}$ 装置 の方が高かった。この結果は異なった装置間で, しかも, 同一症例 の比較結果ではないので単純に結論づけられないが，医師による視 覚評価結果もこれと同じ傾向を示した. 磁場強度が小さくなること による，もっとも大きい効果にはSNRの低下があり，この効果は, 検出能の低下に㗢くものと考えられる. しかし, 低磁場装置の検出 能が向上した要因としては, T1, T2, T2*值や, 磁化率効果の変化 が考えられ，現在，詳細を検討中である.

393 balanced TFEを用いたラパコレ術前MR-virtual laparoscopy の有用性の検討

聖マリアンナ医科大学横浜市西部病院・画像診断部 鈴木清文

宮崎寿哉，西山健一，平野智之，久米由香，菊池康隆

【目的】近年, ラパコレの普及に伴い, 術前に胆道系や周辺血管の情 報を得る事が胆管損傷や出血を防ぐ上で重要となっている．今回 我々は第32回秋季大会で報告した「balanced sequenceを用いたMRvirtual laparoscopy (MR-VL)」での問題点(細血管の描出不良・胆囊管 の検出率)の改善を試みたので報告する.

【使用機器】philips社製 Gyroscan Intera 1.0T power，（株) AZE Virtual place Advance

【方法】1) 胆囊管 - 肝動脈の描出率向上, 及び胆囊動脈描出の為, パ ラメーターの再検討を行った. 従来の呼吸同期に加え心電図同期併 用による撮像を試みた，2)脂肪抑制b-TFEを用いて術前に作成した MR-VL画像と実際の術中videoを対比し，有用性を検討した。

【結果】1)TFE-factorの検討により呼吸によるぶれが軽減し，胆襄管 . 肝動脈の描出率が向上した. slice厚を薄くする事で元画像での胆鞟 動脈の描出に改善が認められたが, MR-VLでは表示困難であり,さ らにslice枚数の増加に伴い撮像時間延長の問題が生じた。心電図同 期併用では呼吸同期のみで得られた画像に比べ, 描出能の改善に顕 著な成果は得られなかった。最適と思われた撮像条件：3D bTFE+SPIR TR/TE/FA : 4.8/2.4/90 FOV : 300 matrix : 294×512(r) slice : $1.4 /-0.7 \mathrm{~mm}, 2.0 /-1.0 \mathrm{~mm}$ TFE-factor: 105 shot-interval : shortest NSA：2 scantime 0:47 2 )術中video と対比した視点からMR-VL画 像を作る事で胆嚢管の走行や, 総胆管との合流パターンの確認を術 者の視点に近づける事が出来た。

【結語】MR-VL画像は術者の視点から胆道系やその周囲の血管構造を 確認でき有効であると評価できた。しかしながら呼吸の不安定な被 検者に㧍いて今後の課題が残った。

394 LAVA (Liver Accelerated Volume Acquisition)法の基礎的 検討 聖隷浜松病院·放射線部 石井 恵, 杉村正義, 山東陽子, 原田成崇 伊藤和彦，石川英男

【目的】LAVA (Liver Accelerated Volume Acquisition)法は3D撮像にお いて slice encored方向にも partial date収集し脂肪抑制pulseを適正化さ せた撮像法である。これにより撮像時間を短縮することが可能と なった。これにより従来の 3Defgreと同一撮像時間ならば，さらな る高分解能化することができ，また広範囲を撮像することも可能と なる。そこで今回, L A V A 法の基礎的検討を行い, 従来の 2DFSPGR，3Defgre法との比較を行ったので報告する。

【方法】使用装置はGE社製 SIGNA TWIN SPEED EXCITE HD，使用 コイルは 8ch body array coilを使用した。ファントムは水道水，サラ 夕゙油, $\mathrm{NiCl}$ ，希釈 $\mathrm{Gd}$ 溶液 ( $0.5 \mathrm{mmol} / \mathrm{ml} \times 1000 \sim 3000$ 倍)，寒天 (1\% $3 \%$ )を用い自作し，1)LAVA法抢よび3Defgre法にてFlip Angleを 5 〜30 まで変化させて撮像した. 2) Flip Angle 90の 2DFSPGR法を TR100〜200msecと変化させて撮像した。得られた画像より SNR, CNRで此較した。その際レシーブバンド幅 $83 \mathrm{kHz}$ ，スライス厚/ ギャップ 5/0 mm, matrix 256×128とした.

【まとめILAVA法を用いることにより従来の 3Defgre Dynamic撮像よ り高分解能でSNの良い画像が得られるものと思われる。さらにやや SNが劣るものの，2DFSPGRと比較し短時間で広範囲を撮像するこ とができる．このことより幾分撮像時間を延長することで広範囲, 高分解能で撮像し, 従来の撮像以上の情報を提供することが可能で あると考えられる。

\section{5 肝臓ダイナミックMRIにおける至適動脈優位相の撮像タイミ ングの検討}

虎の門病院 · 放射線部 濱田祐介, 高橋順士，吉原千治，吉原美保 田野政勝，辻 良憲，森内啓三郎，鈴木 斉

【目的】ダイナミックMRI検査において動脈優位相を得る方法として 当院では, bolus tracking法の一つであるCARE Bolus法を用いて撮像 を行っている．しかし，CARE Bolus法のモニタリングの励起中の騒 音により本スキャンの呼吸停止の合図が聞き取れない場合もしばし ば見られた，そこで，CARE Bolus法で得られた動脈優位相の撮像開 始時刻を参考にして呼吸停止の合図が聞き取れない場合の至適動脈 優位相の撮像タイミングについて検討を行ったので報告する。

【方法】MRI装置はSIEMENS社製 MAGNETOM Symphony1.5Tを使用 し，MRI injectorは根本杏林堂製 Sonic shot 50を使用した，造影剤の 注入条件は $3.0 \mathrm{~mL} / \mathrm{sec}$ と固定し，モニタリング画像の撮像断面は矢状 断とした. CARE Bolus法で得られたモニタリング画像より，造影剂 注入から腹腔動脈 (上腸間膜動脈)の描出される時間を調べた。この データを参考にしてCARE Bolus法の励起中の騒音で呼吸停止の合図 が聞き取れない患者における撮像夕イミングを決定した。

【結果】腹腔動脈描出直後を撮像開始時間とすると, 撮像開始時間は 造影剤注入後 10 秒から 32 秒で中央值 15 秒であった。これらの解析よ 


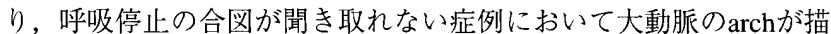
出された時点でモニタリングを停止し，その直後に撮像開始の合図 をすることで良好な動脈優位相が得られた。

【考察】高齢者や難聴者においてモニタリング中の騒音で呼吸停止の 合図が聞き取れず本スキャンが呼吸停止不良例となる場合があっ た。疾患や動脈硬化などを考慮し，撮像直前まで造影剤の血行動 態をモニタリングすることで肝臟への造影剤の到達の予測ができ， 最適な動脈優位相が得られたと考えられる。

\section{6 上腹部撮影におけるPropellerの有用性}

聖路加国際病院・放射線科 三田村誠，二瓶 努，砂塚 亘 鈴木弘和，島田和充，中村美穂，長下部干春，船田重和

【背景】近年MRI装置の急速な発展により，鎮静が困難な小児や高齢 者, 安静下にいることが困難な患者などの動きのある被写体でも Propellerを用いて動きに対する高度な補正が可能となり頭部撮影に 使われだしてきている，そのPropellerの特性を生かし，上腹部撮影 に用いれば，息止撮影のできない患者や呼吸Gateがうまくとれない 患者にも動きのアーチファクトがほとんど無い，良好な画像を提供 できるのではないかと考えた。

【目的】上腹部撮影にPropellerを用いた画像の有用性について検討し た。

【使用機器】GE横河メディカルシステム社 Signa EXITE XI Ver11 リ サーチモード

【対象】息止めが不可能，呼吸Gateの安定しない患者15例(同意を得 る), 健常ボランティア10例. 内訳は, 男性16例, 女性 9 例で年齢 は46士4.5歳.

【方法】(1)FIESTAをMulti-Phaseで同一スライス20秒間撮影し，横隔膜 の動きをSI方向で測定し，被写体固有の動き幅を記録. (2)(1)を動き 幅事に応に゙, $12 \mathrm{~cm}$ 以上A群, $12 \mathrm{~cm} \sim 7 \mathrm{cmB}$ 群, $7 \mathrm{~cm}$ 未満C群と分け, Propellerで撮影したT2 画像と, 通常, 当院で息止めが不可能, 呼吸 Gateの安定しない患者に使用しているFSEを用いたT2，4NEXを撮影 する。. (3)(2)で分けられた各群の画像の有用性を放射線科医 4 名と技 師 6 名で優, 良, 不可の 3 段階に視覚評価した。

【結果】い゙れの群の評価に扔いても，Propellerが4NEX-T2 より劣る と判定された画像はなく，有用な画像を得ることができた。

【結語】Propellerを用いたT2 画像は，息止めが不可能，または呼吸 Gateの安定しない患者において高い診断能を示した。

\section{7 骨盤領域T2WIにおける呼吸性アーチファクト低減の試み一} k spaceからの検討一

石心会川崎幸病院・放射線科 中 孝文，斎藤一樹，石田和史

【目的】骨盤領域では呼吸性アーチファクトの影響による画質低下を 防ぐため様々な対策が講じられてきたが，どの方法でも撮影時間や 分解能などを犠牲にする必要があった，今回我々はPause機能を併用 してMulti Breath Holdで撮像すると高い画質を保ったまま，その影 響を低減させる事が可能ではないかと考えた．さらに息止め回数を より少なくし患者の負担を軽減する為に，k spaceの低周波成分から 充填する撮像パラメーターの検討も行った。

【使用装置】GE社製 Signa Lx 1.0T Ver9.1

【方法】1. ETLによる充填方法を検討した．2．RBWによる充填方法 を検討した. 3. NEXによる充填方法を検討した．4. TRによる充填 方法を検討した．5.TEによる充填方法を検討した．6. Pause回数 を変化させGd水溶液を撮像し，SNR，CNRを測定した，7，1５で の結果を基にボランティア撮像し，最適なPause回数を検討した。 【結果】k spaceの低周波成分から充填するにはETLは約20, RBWは約 $20 \mathrm{kHz}$ ，TRは $2500 \mathrm{~ms}$ 以上，TEは $100 〜 110 \mathrm{~ms}$ の時に認められた。 NEXには依存しなかった。またSNRはPause回数による影響を受けな かった。CNRは信号強度の低いGd水溶液にばらつきが認められた
が，ある程度高いものでは安定していた。ボランティア撮像では息 止め回数が多いほどかえって撮像時間が延長してしまい，1回の息 止めで充分にアーチファクトを抑制した画像が得られた。

【考察】れまで高い画質のまま，呼吸性アーチファクトによる影響 を無視できるくらいの撮像法は確立されていなかった。しかし，今 回の検討において撮影時間の先頭での息止めによって分解能やSNR を劣化させることなく呼吸性アーチファクトを低減する事ができ た。

398 Fast Spin EchoT2強調画像における子宮 3 層構造の信号強 度変化とコントラスト

日本医科大学付属千葉北総病院 - 中央画像検査室 加藤丈司 阿部雅志，仲田佳広，結城聖子，富里謙一，渡辺典男，川村義彦 【目的】婦人科領域のMRIに打いて性成熟期女性の子宮は $\mathrm{T}_{2}$ 強調画像 で特徴的な 3 層構造を示す.内膜は高信号に次に最内筋層とされる junctional zoneが低信号に, 最外層の筋層が中等度の信号に描出され る、 $\mathrm{T}_{2}$ 強調画像においては子宮筋層の厚さや内膜の状態およびその 位置関係を明瞭なコントラストにて描出することが重要である。今 回Fast Spin Echo法 $\mathrm{T}_{2}$ 強調画像に扔ける子宮の信号強度变化と 3 層の 相互コントラストについてシミュレーション及び臨床において検討 したので報告する。

【方法】子宮 3 層の信号強度抢よび内膜-junctional zone と筋層junctional zoneのコントラストをシミュレーションによりもとめた. さらに臨床において撮像を行い比較検討した，使用機種は超伝導型 MR装置Signa (GE社, 静磁場強度1.5T) である。

【結果及び考察】内膜-junctional zoneのコントラストはTR $8000 \mathrm{~ms}$ 0.14 , 筋層-junctional zoneは $4000 \mathrm{~ms}$ から $6000 \mathrm{~ms}$ で 0.05 を示した。 内 膜-junctional zoneが筋層-junctional zoneに比べて高いコントラストが 得られること，また，臨床においてTRの設定が撮像時間の延長と直 結し，動きによるアーチファクトが懸念されるなど考慮した場合 4000ms-6000msが良いと思われる. TEに関しては内膜-junctional zone のコントラストは $150 \mathrm{~ms}-200 \mathrm{~ms}$ で約 0.125 , 筋層-junctional zoneでは 100-130msで0.05であった. TRと同様に筋層-junctional zoneのコント ラストが最大となるTEの設定が良いが，T緩和による信号減衰を考 慮して約100msが有効であった。本検討から子宮コントラストを向 上し良好な $\mathrm{T}_{2}$ 強調画像を得ることができた。 また，子宮コントラス トの向上は画像診断の正診率向上に有効と思われた。

399 排便機能MRI(MRDefecoImage)に関する基碟的検討一直腸 内充填物ファントム評価一

医療法人新生会高の原中央病院・放射線科 佐々木輝, 中村裕二 磯村忠範

(株)国際電気通信基礎技術研究所・脳活動イメージングセンタ 藤本一郎，赤土裕子，島田育廣

【目的と背景】直腸手術後には排便回数の増加や便意があるにも関わ らず排便がないなどの排便機能障害を訴える方も少なくない，排便 機能を客観的に評価するためのMRDefecolmageに用いる直腸充填物 および撮像シーケンスについてファントムにて検討を行ったので報 告する。

【使用装置】Siemens社製 1.5T MRI装置

【実験方法】1，自作ファントムを作成し，trueFISP，HASTE，T1FLASH (Fatsatあり・なし)で撮像（試料）・Gd造影剤（濃度： $0.05 \mathrm{mmol} / \mathrm{l}, 0.1 \mathrm{mmol} / \mathrm{l}, 0.2 \mathrm{mmol} / \mathrm{l}) \cdot$ 生理食塩水・食用油・筋肉・ マッシュポテト+通常濃度フェリセルッ(体積比 $1: 3,1: 2) \cdot マ ッ$ シュポテト+水(体積比 $1: 2$ ) 2 ，各試料のSNRをシーケンスごとに 測定 3, 各試料のCNRをシーケンスごとに測定.

【結果】T1-FLASHではSNR・CNRともにフェリセルツ+ポテトが高く なった，trueFISPにおいてはSNR・CNRともに水分量の多いものほ 